\title{
Discussion on the Application of LS-DYNA in Superfine Grinding of Wheat Bran
}

\author{
CHENG Min, LIU Baoguo*, CAO Xianzhou
}

School of Mechanical and Electrical Engineering, National Engineering Laboratory of Wheat \& Corn Further Processing, Henan University of Technology, Zhengzhou 450001, China

\begin{abstract}
Superfine grinding, involving the fragmentation mechanism of wheat bran cell tissue, is being employed by milling industry. In order to determine the effect of wheat bran cell tissue on the fragmentation mechanism when using superfine grinding, a technical scheme of the nonlinear finite element numerical simulation method based on LS-DYNA is proposed in this paper. The physiological characteristics of wheat bran structural layers including outer pericarp, intermediate layer and aleurone layer are examined first, and then the mechanical properties of wheat bran structural layers and their effects on the super fine grinding process are analyzed. Secondly, the explicit time integration algorithm of LS-DYNA is introduced, and the application feasibility of LS-DYNA in the analysis of wheat bran superfine grinding mechanism is discussed. Finally, the specific application of LS-DYNA in the determination of grinding form and load, the selection and design of the grinding media and the selection of grinding temperature are discussed in detail in the process of superfine grinding for wheat bran cell tissue. The above research provides a theoretical basis for selecting and developing the equipment and technology suitable for wheat bran superfine grinding, and lays a theoretical foundation for enhancing the quality and efficiency of wheat bran superfine grinding.
\end{abstract}

Keywords: LS-DYNA; Wheat bran; Superfine grinding; Fragmentation mechanism; Cell tissue

\section{Introduction}

According to the 13th five-year plan for the country's scientific and technological progress issued in July 28, 2016, the State Council of China has taken superfine grinding technology into the special column of modern food manufacturing technology. Compared with conventional grinding, superfine grinding belongs to cellular level pulverizing, which generally refers to the process of crushing the material from $0.5-5 \mathrm{~mm}$ to less than $10-25 \mu \mathrm{m}$ by mechanical or hydrodynamic method ${ }^{[1]}$. After superfine grinding, the aleurone layer of wheat bran is disrupted allowing cell walls to be broken, which helps nutrients to be more efficiently released. The outer pericarp and intermediate layer of wheat bran also contains fibrous tissues and breaking up cells can help to improve the palatability of bran food and increase the added value of wheat bran ${ }^{[2-4]}$. In the superfine grinding process, the crushing performance of wheat bran cell tissue is restricted by macro crushing factors of crushing equipment such as crushing form, crushing load, grinding medium, grinding temperature and so on. However, at present, no one has studied the superfine grinding mechanism of wheat bran at the cellular level. According to the grinding process of cell tissue, the superfine grinding of wheat bran has typical characteristics of transient speed and high nonlinearity,

Received: 29 September 2017 /Accepted: 17 November 2017.

Supported by National Natural Science Foundation - Henan Joint Fund Key Support Project (No. U1604254) and Open Subject of National Engineering Laboratory of Wheat \& Corn Further Processing (No. NL2017010).

*Corresponding author. E-mail: bgliu1978@sina.com

CHenan University of Technology 2018

CHENG M, LIU B G, CAO X Z. Discussion on the Application of LS-DYNA in Superfine Grinding of Wheat Bran[J]. Grain \& Oil Science and Technology, 2018, 1(3): 138-144. and there is a significant advantage that the nonlinear finite element method is used to explore the fragmentation mechanism of wheat bran cell tissue.

At present, the nonlinear finite element numerical simulation method can be divided into two types ${ }^{[5]}$. One is based on a variety of the finite element theory to write the program and then carry out the finite element simulation analysis. For example, Wang Zhen of Zhejiang University studied the collision, fracture and penetration of thin shell structures based on an analysis program by using the vector finite element theory ${ }^{[6]}$. However, this method is time-consuming, laborious, and not versatile. The other one is based on the existing commercial finite element software to carry out finite element simulation analysis. At present, the most of nonlinear finite element numerical simulation analysis adopts this simple and versatile method. LS-DYNA is recognized as the most outstanding nonlinear finite element numerical simulation software with the functions of explicit analysis and implicit analysis ${ }^{[7]}$. The explicit time integration algorithm is the main algorithm of LS-DYNA, including 2D and 3D algorithm, which can be used to analyze the complex nonlinear dynamics problems such as material nonlinear, large deformation, crack propagation, dynamic contact analysis and failure analysis, and the transient thermal coupling problems. In addition, LS-DYNA also provides ALE algorithm, adaptive mesh repartition algorithm, SPH and EFG algorithm, which can deal with all kinds of highly nonlinear and large deformation problems. The implicit analysis of LS-DYNA can be used as a supplement to explicit analysis, including the modal analysis, implicit structural analysis, heat conduction analysis and so on. Because of powerful numerical simulation ability, LS-DYNA has been applied in many engineering fields, such as automotive engineering, aerospace, civil engineering, defense 
industry, metal processing, bioengineering, etc. ${ }^{[8-10]}$

Although LS-DYNA has been successfully applied in various fields, there have been no reports on the application of wheat bran superfine grinding. In this paper, the necessity of using LS-DYNA to simulate and analyze the fragmentation mechanism of cell tissue is described firstly based on the difference between cell tissue and mechanical properties of wheat bran, and the effect of the grinding process. Then, the rationality of using LS-DYNA to simulate and analyze the fragmentation mechanism of cell tissue is explored on account of the feasibility and implementation of LS-DYNA explicit time integration algorithm for wheat bran superfine grinding. Finally, the application of LS-DYNA in the superfine grinding of wheat bran from the aspects of grinding form, crushing load, grinding medium and crushing temperature is discussed, and the direction of effort is pointed out for revealing the fragmentation mechanism of wheat bran superfine grinding at the cellular level.

\section{Superfine Grinding Process of Wheat Bran}

\subsection{Cell Tissue Structure of Wheat Bran}

Bran is the outer structural layer of wheat grain, as shown in Fig. 1, which from the outside to the inside in turn include inner pericarp, outer pericarp, seed coat, transparent layer and aleurone layer. The weight of wheat bran accounts for about $22 \%-25 \%$ of wheat grain. The inner pericarp, the seed coat and the transparent layer adhere together and are generally known as the intermediate layer ${ }^{[11]}$. Of three kinds of wheat bran tissue structural layers, the aleurone layer accounts for the largest proportion in weight, about $48 \%-52 \%$ of wheat bran, outer pericarp and intermediate layer accounts for about $30 \%$ and $20 \%$ of wheat bran, respectively ${ }^{[12]}$.

As shown in Fig. 1, there are important differences in cell tissue structures of outer pericarp, intermediate layer and aleurone layer of wheat bran. Due to the lack of continuous cellular structure, the outer pericarp is a spontaneous fracture layer. The intermediate layer consists of transverse cells and tubular cells arranged in a crisscross pattern, all of which are diploid fibroblast. The shape of the transverse cells is long cylindrical and its size is about $125 \mu \mathrm{m} \times 20 \mu \mathrm{m}$. The long axis of the transverse cells is perpendicular to the long axis of grain. The transverse cells are arranged closely and there are no gaps between the cells. The tubular cells are essentially the same as the transverse cells in size, but are arranged in parallel with the long axis of grain. The tubular cells are not arranged closely, and there are gaps between the cells ${ }^{[13]}$. The aleurone layer is composed of single, thick, triploid living cells, which are true cereal cells pollinated by wheat cells ${ }^{[14]}$. The shape of the aleurone cells, which contain cell contents coated by a cell wall, is rectangular with the size of about 35-50 $\mu \mathrm{m}$. Cell contents include fatty phospholipids ball with protein carbohydrate particles and diameter of $0.25-3.5$ $\mu \mathrm{m}^{[13]}$. Aleurone cell wall, which thickness is $3-4 \mu \mathrm{m}$, is mainly composed by cellulose such as glucan and xylan, and the ratio of insoluble to soluble dietary fiber is 9:1. However, non-aleurone cells mostly do not contain cell contents, and the cell wall is mainly composed of arabinoxylan, lignin and cellulose, and the polysaccharide molecules are linked by ferulic acid dehydrogenomer ${ }^{[12]}$. From above, it can be concluded that the grinding characteristics of wheat bran are not the same as differences in cell tissue structures in the superfine grinding process of wheat bran. It is difficult to observe the crushing process of wheat bran cell tissue by means of superfine grinding experiment, so that it is necessary to explore the crushing rules of wheat bran cell tissues by carrying out nonlinear finite element numerical simulation analysis.

\subsection{Mechanical Properties of Wheat Bran}

The macro mechanical properties of wheat bran are different because of the different cell tissue of the wheat bran ${ }^{[13,15-16]}$, as shown in Fig. 2.

The outer pericarp mainly shows the elastic strain process, and there is almost no plastic strain process. The ultimate strain of the outer pericarp remains unchanged basically in the longitudinal and radial directions, while the ultimate stress changes greatly, indicating that the crushing force in different directions was significantly different during the superfine grinding process. The outer pericarp can be considered as an anisotropic elastic material. The stress-strain curves of the intermediate layer and the aleurone layer are relatively close, so that the elastic strain process and the plastic strain process are shown at the same time. In the longitudinal direction, the aleurone layer is greater than the intermediate layer in the ultimate stress and is less than the intermediate layer in the ultimate strain. However, in the radial direction, the intermediate layer is greater than the aleurone layer in the ultimate stress and the ultimate strain. Compared with the outer pericarp, the intermediate layer and the aleurone layer can be considered as two isotropic bilinear kinematic materials because the variations of the stress and strain in the longitudinal and radial direction are relatively small. Compared with the aleurone layer, the change of ultimate stress and ultimate strain of the intermediate layer is more significant. Due to the difference in the mechanical properties of wheat bran structural layers, it may lead to separation of layers, which firstly overcoming the interlayer binding force and then causing breakage of cell tissue in the superfine grinding process. In view of the differences in the mechanical properties of wheat bran structural layers, the crushing factors such as crushing form, crushing load and grinding medium should also be different ${ }^{[17]}$, and it is necessary to carry out the finite element numerical simulation analysis at the cellar level, in order to determine what will cause the more complex fragmentation mechanism of superfine grinding of wheat bran.

\subsection{Grinding Process of Wheat Bran}

Because of the differences in mechanical properties of wheat bran, the grinding process of cell tissue is fairly complex. Before wheat bran is subjected to superfine grinding, it can be pre-treated by multistage grinding, so as to reduce the particle size of wheat bran, improve the evenness of wheat bran and prevent smaller sized particles of wheat bran from excessive crushing. According to the graded grinding scheme as shown in Table 1, wheat bran is screened and particles with different sizes 


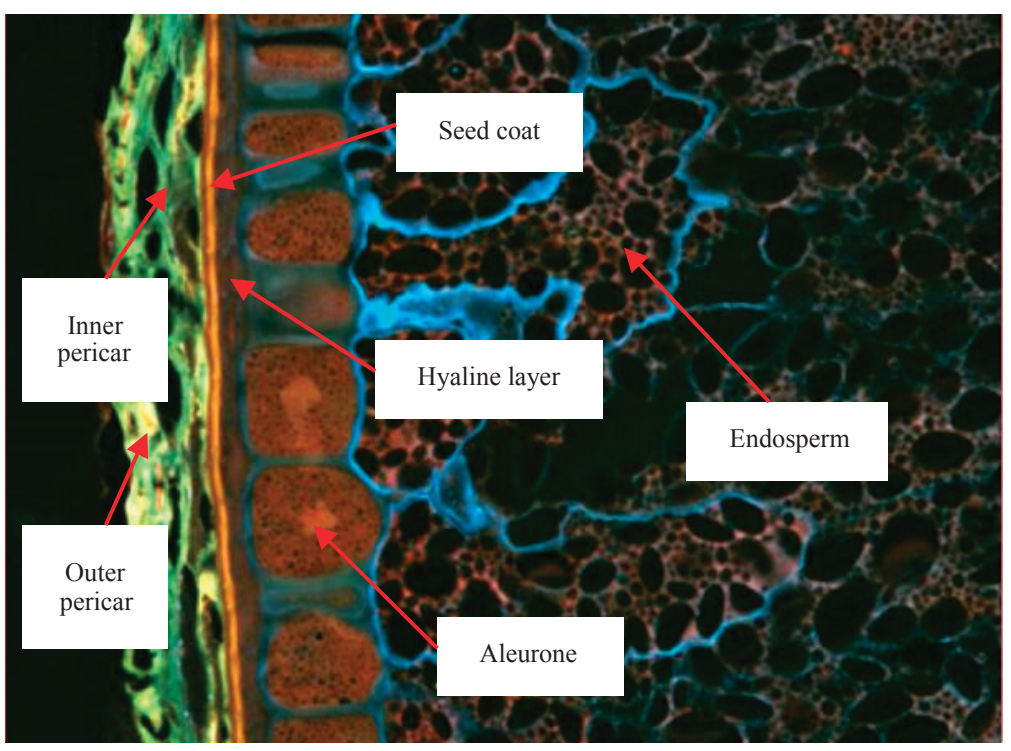

Fig. 1 Cell tissue structure of wheat bran ${ }^{[11]}$
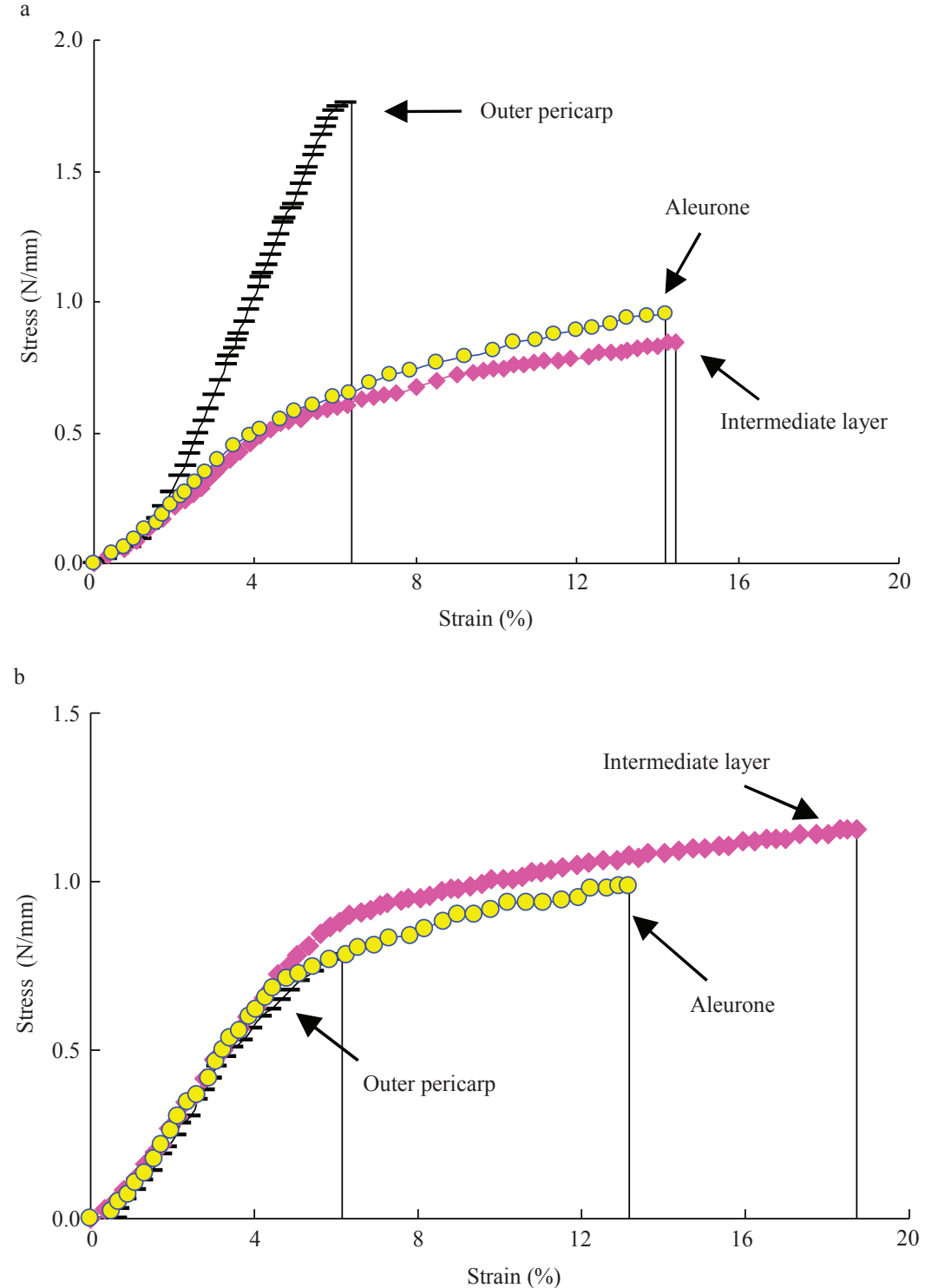

Fig. 2 Stress and strain curves of wheat bran structural layers on longitudinal (a) and radial (b) directions ${ }^{[13]}$ 
Table 1 Graded grinding scheme of wheat bran

\begin{tabular}{ccccc}
\hline Grade & Ultra large particle size & Large particle size & Medium size & Small size \\
\hline Sieve mesh number & $<5$ & $5-10$ & $10-20$ & $20-50$ \\
Particle size of wheat bran $(\mu \mathrm{m})$ & $>4000$ & $1700-4000$ & $850-1700$ & $280-850$ \\
\hline
\end{tabular}

are obtained firstly. Then the wheat bran particles are put into the lower grade grinders, continuous screening and grading after completion of the grinding. The graded bran particles continue to be thrown into the lowest grade grinding until the average particle size of wheat bran $\mathrm{D}_{50}$ is less than $280 \mu \mathrm{m}$. Finally, with the aim of obtaining the superfine grinding powder, the wheat bran particles are put into superfine grinder for superfine grinding.

Research shows that when the particle size of wheat bran is less than $280 \mu \mathrm{m}$, the aleurone layer, the intermediate layer and the endosperm layer are separated from each other ${ }^{[13]}$. However, the outer pericarp and the intermediate layer have begun to separate when the grain size is less than $460 \mu \mathrm{m}$. The main reasons are that the mechanical properties of the outer pericarp and the intermediate layer are different significantly, and there are some gaps between the two layers, as shown in Figs. 1 and 2. It can be concluded that the geometric and physical properties of wheat bran granules will also change with particle size in the graded grinding pretreatment process of wheat bran. The various grinding methods, crushing load, grinding medium and grinding temperature should be selected according to the difference of crushing objects and the requirements of grinding grain size. Therefore, in the graded grinding pretreatment and superfine grinding process of wheat bran, it is necessary to use the nonlinear finite element numerical simulation method to determine the best crushing form, crushing load, grinding medium and grinding temperature, which provides a theoretical basis for the optimal design of the superfine grinding process of wheat bran.

\section{Application Analysis of LS-DYNA in the Superfine Grinding of Wheat Bran}

In view of the strong computing power of LS-DYNA, ANSYS and LSTC co-developed ANSYS/LS-DYNA in 1996. Now it has been the most frequently used and most popular finite element analysis software in China. Its core computation function is built on explicit time integration algorithm.

\subsection{Explicit Time Integration Algorithm for LS-DYNA}

The superfine grinding process of wheat bran has the characteristics of large deformation, highly nonlinear and transient mutability. When considering the effect of structural damping on the cells tissue of wheat bran, the dynamics differential equation of wheat bran particles can be expressed as ${ }^{[7]}$ :

$$
M \ddot{x}(t)=P(t)-F(t)+H(t)-C \dot{x}(t)
$$

Where $M$ is the mass matrix of wheat bran particles; $C$ is damping matrix; $\ddot{x}(t)$ and $\dot{x}(t)$ are nodal acceleration vector and nodal velocity vector; and $P(t), F(t)$ and $H(t)$ are load vector, internal force vector (including unit internal force and contact force) and hourglass resistance vector of grinding system respectively. LS-DYNA uses the explicit central difference method to integrate Equation (1) in terms of time. In the case of knew solutions of the $0, \ldots, t_{n}$ time step, the basic recursion format to get the solution of $t_{n+1}$ time step is as follows:

$$
\left\{\begin{array}{l}
\ddot{x}\left(t_{n}\right)=M^{-1}\left[P\left(t_{n}\right)-F\left(t_{n}\right)+H\left(t_{n}\right)-C \dot{x}\left(t_{n-1 / 2}\right)\right] \\
\dot{x}\left(t_{n+1 / 2}\right)=\dot{x}\left(t_{n-1 / 2}\right)+\ddot{x}\left(t_{n}\right)\left(\Delta t_{n-1}+\Delta t_{n}\right) / 2 \\
x\left(t_{n+1}\right)=x\left(t_{n}\right)+\dot{x}\left(t_{n+1 / 2}\right) \Delta t_{n}
\end{array}\right.
$$

Wherein, $t_{n-1 / 2}=\left(t_{n}+t_{n-1}\right) / 2, t_{n+1 / 2}=\left(t_{n+1}+t_{n}\right) / 2, \Delta t_{n-1}=t_{n}$ $-t_{n-1}, \Delta t_{n}=t_{n+1}-t_{n} . \ddot{x}\left(t_{n}\right), \dot{x}\left(t_{n+1 / 2}\right)$ and $x\left(t_{n+1}\right)$ are nodal acceleration vector of $t_{n}$ moment, nodal velocity vector of $t_{n+1 / 2}$ moment and nodal position vector of $t_{n+1}$ moment respectively, and the meaning of other parameters can be analogized. When the displacement $x\left(t_{n+1}\right)$ of $t_{n+1}$ moment is obtained by the Formula (2), the element stress and strain at $t_{n+1}$ moment can be obtained by replacing $x\left(t_{n+1}\right)$ into the geometric equation and the physical equation. Although the computational efficiency of the explicit central difference method is high, the integration algorithm is not unconditionally stable. LS-DYNA adopts the variable step integration method, which requires that the time step length $\Delta t$ is less than the critical step length $\Delta t^{\mathrm{e}}$, and there is

$$
\Delta t<\Delta t^{\mathrm{e}}=\alpha\left(l^{e} / c\right)
$$

Where $\alpha$ is the time step factor, and generally $\alpha=0.8-0.98$; $l^{\mathrm{e}}$ is the characteristic size of the unit; $c$ is the wave velocity of the unit longitudinal wave. When the finite element units are different, the methods of choosing parameters of the characteristic size and the wave velocity of the longitudinal wave are different too ${ }^{[7]}$.

\subsection{Application Feasibility Analysis of LS-DYNA in the Superfine Grinding of Wheat Bran}

From a mechanics point of view, the most notable technical characteristics of LS-DYNA are the handling of highly nonlinear problems such as dynamic contact of objects, large deformations, material nonlinearities, as well as high-speed transient problems such as explosions, impacts, pouring, and material forming ${ }^{[7]}$.

There are also highly nonlinear problems and high speed transient problems in the superfine grinding process of wheat bran, such as mechanical deformation and rupture of cell, penetration of cell wall, and transient breakage of fibrous tissue. Therefore, it is feasible to use LS-DYNA to detect the crushing laws of cell tissue during superfine grinding of wheat bran. LS-DYNA finite element simulation analysis can replace the high-cost prototype experiment, which can significantly reduce the research cost and shorten the study cycle. In addition, the influence of some technological parameters of grinding equipment on the macro movement characteristics of wheat bran particles in crushing chamber can be observed only by using the superfine grinding experiment of wheat bran, and it is still very difficult to determine the breaking rules of wheat bran cell tissue. To sum up, finite element numerical simulation analysis using LS-DYNA based on finite element analysis model of cell tissue in wheat bran structural layers contributes to investigating the effects of crushing form and crushing load of grinding equipment 
on crushing performance of the cell tissue of wheat bran, getting the best crushing form and crushing load; helps to reveal the influence rules of material, shape, size and other parameters of grinding medium on crushing performances of wheat bran cell tissue in the superfine grinding, obtain the best grinding medium; and also conduces to determining the effect mechanism of crushing temperature on crushing performance of wheat bran cell tissue, revealing rationality of low temperature grinding and getting the best grinding temperature.

\subsection{Application Scheme Analysis of LS-DYNA in the Superfine Grinding of Wheat Bran}

ANSYS/LS-DYNA has convenient pre-processing and post-processing functions based on the operation interface and the unified database of the ANSYS, and also has powerful capability of nonlinear computing analysis which relies on the LS-DYNA solver. ANSYS/LS-DYNA can be used to simulate and analyze the fragmentation of cell tissue during superfine grinding of wheat bran, and the detailed applications are as follows:

1) Preparation of analytical data. The dynamic mechanical thermal analyses (DMTA) with cooling system were used to measure the elastic modulus, Poisson's ratio, yield strength and tangent modulus of wheat bran under different temperatures.

2) Establish analytical models. ANSYS Workbench 14.0 was chosen as the finite element numerical simulation analysis environment. According to the cell tissue of wheat bran structure layers, the geometric model of the outer pericarp, intermediate layer and aleurone layer and the geometric model of grinding medium were established using SolidWorks 2012, and were imported into the Design Modeler (DM) platform. On this basis, the finite element mesh is divided and the finite element model is formed.

3) Output K file. According to specific research problems of wheat bran superfine grinding, the contact surface and boundary conditions of the finite element analysis model was defined and initial load or initial speed was applied. Then the parameters on input, process control and output were set up in finite element simulation analysis, and $\mathrm{K}$ files were obtained.

4) Using LS-DYNA to solve the problem. The K file is submitted to the LS-DYNA solver, and the solution parameters are set for solving.

5) Post-processing results. By using the post-processing program called LS-PrePost 4.0 to visualize and analyze the calculating data, the crushing rules of wheat bran during the superfine grinding process can be obtained.

In the above application plans, the finite element mesh division of wheat bran cell tissue is one of the vital preprocessing steps for finite element simulation analysis. The mesh quality of wheat bran cell tissue directly affects the accuracy of the solution. At present, some domestic scholars have studied the static characteristics of plant cell tissue by finite element analysis, which finite element mesh division have significant references ${ }^{[18-20]}$.

\section{Application Discussion of LS-DYNA in Superfine Grinding of Wheat Bran}

Due to the macro superfine grinding experiment is difficult to observe the crushing process of wheat bran cell tissue, and more difficult to ascertain for superfine grinding form, crushing load, grinding medium, grinding temperature and other macro crushing factors, the finite element numerical simulation can only be carried out with the help of LS-DYNA for superfine grinding of wheat bran.

\subsection{Application of the Selection of the Crushing Form and Load}

Theoretically speaking, the wheat bran powder obtained by multistage crushing pretreatment can be regarded as mixed by particles of outer pericarp, intermediate layer and aleurone layer. The crushing performance of wheat bran particles is different because of the differences in mechanical properties of wheat bran structural layer. Therefore, when wheat bran is treated by superfine grinding, different crushing forms and crushing load should be adopted in each wheat bran structure layer. As shown in Fig. 3, the basic forms of mechanical crushing mainly include extrusion, impact, friction, and shear.

The crushing forms of wheat bran depend on the crushing performance of structural layer cell tissue. In theory, it is difficult for the flexible material to impact crushing, and it is appropriate to use shear and friction crushing. On the contrary, it is not easy for brittle rigid materials to shear crush, but it is more effective to impact crush or extrusion crush. Judging from the grinding process, most of the deformation of flexible materials cannot play the role of crushing, while brittle and rigid materials will produce a crushing effect when the deformation is very small. As the deformation needs to consume energy, the greater the deformation is, the greater the consumption of energy ${ }^{[21]}$. Therefore, from the point of grinding energy consumption, flexible materials consume more energy than brittle rigid materials at the same particle size. Due to the different crushing performance of wheat bran structural layer cell tissue, finite element simulation analysis based on LS-DYNA is the main way to select suitable crushing forms and crushing load. Therefore, according to the LS-DYNA calculation and analysis steps, the finite element analysis models of structural layers cell tissue should be established to analyze by simulating the mechanical effect of various crushing forms and crushing load on cell tissue, so as to determine the best suitable crushing forms and crushing load of wheat bran superfine grinding.

\subsection{Application of the Selection and Design of Grinding Medium}

In the process of superfine grinding, a large number of medium mills, such as ball mills, stirred mills, vibrating mills and centrifugal planetary mills are needed to achieve refinement of various materials ${ }^{[1]}$, and their work relies on grinding medium. According to the geometry, grinding medium can be divided into three categories: spherical, columnar and irregular. According to the material, grinding medium can be divided into carbon steel, 

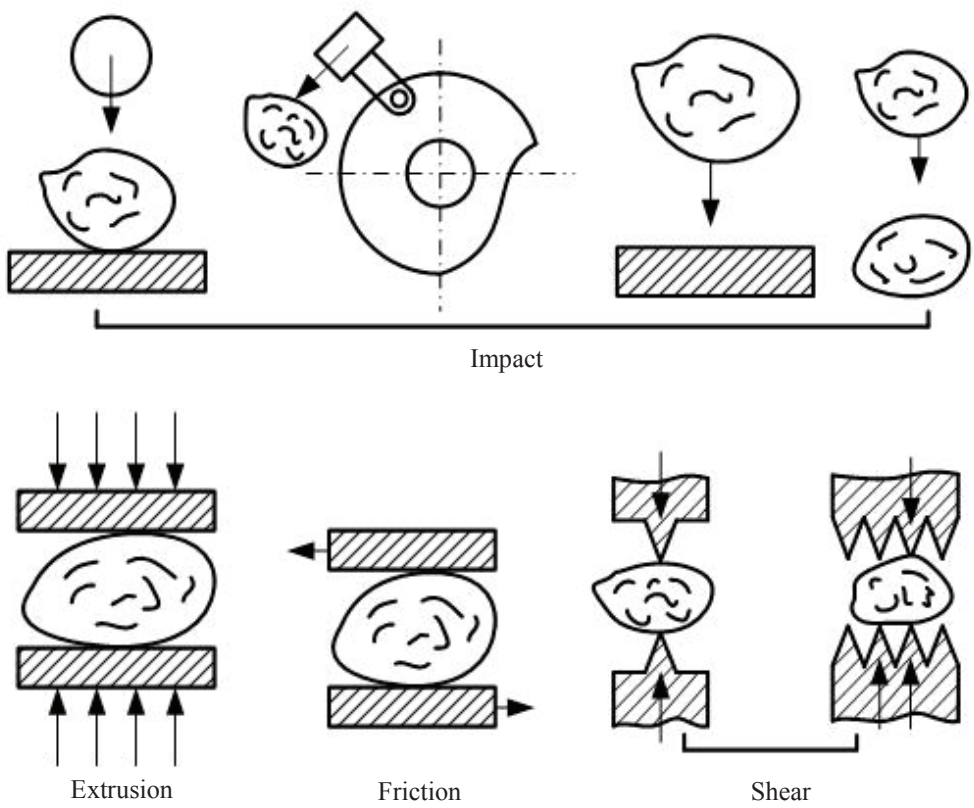

Fig. 3 Basic forms of mechanical grinding

stainless steel, high chromium cast iron, corundum (alumina), glass, agate, zirconia and so on. The material, density, hardness, size, shape, filling rate, ratio and supplementing system of grinding medium are important factors to determine the working performance of the medium mills. Previous research has shown that the material of grinding medium determines the crushing cost, the crushing efficiency and the quality of the product during crushing process ${ }^{[22]}$. The density of grinding medium determines the strength of the impact force, so that the greater the density of grinding medium, the stronger the grinding capacity and the higher the crushing efficiency.

At present, it is partly disputed as to how to determine the shape and size of grinding medium to ensure the best crushing effect of wheat bran in the superfine grinding process. In order to study the problem with the help of experimental methods, many kinds of grinding medium with various shapes and specifications will be required, which will increase the research costs and the research cycle. Therefore, LS-DYNA can be used to simulate the influence of the shape, material and size of grinding medium on the crushing performance of wheat bran cell tissue, and obtain the best grinding medium in different crushing forms. Because the main research problem is the fragmentation mechanism of cell tissue in the superfine grinding process of wheat bran, factors such as gradation and filling rate of grinding medium are not considered. In the finite element simulation, the finite element analysis model of grinding medium should be established first. Then the crushing effect of shear, impact and friction will be simulated between the grinding medium and the cell tissue structure of wheat bran, so that the best grinding medium can be determined according to the simulation results.

\subsection{Application of the Selection of the Crushing Temperature}

The mechanical properties of wheat bran structure layers will change at different temperatures, and have a significant impact on crushing performance of cell tissue ${ }^{[23]}$. Therefore, at the beginning of the 20th century, a low temperature crushing technology was developed to crush the material by the embitterment of dense material at low temperature. In the 1980s, Japan began to study the low temperature grinding of food. Subsequently, the United States, Europe and China have also carried out a number of development studies. Since 2000, some scholars at home and abroad began to study the effect of low temperature grinding conditions on the superfine grinding of wheat bran and the results showed that it is feasible and economical to crush wheat bran in a low temperature environment ${ }^{[24-26]}$. At present the effects of low temperature conditions on the crushing performance of cell tissue of wheat bran and crushing optimum temperature have not been revealed at the micro level.

Because of the differences in the mechanical properties of wheat bran, different grinding methods, crushing equipment and crushing process should be used in theory. However, rigid and friability of the wheat bran structure layers increased with the decrease of temperature under low temperature environment. The difference of mechanical properties of wheat bran began to reduce, and the fragmentation energy of wheat bran cell tissue also gradually decreased, which is beneficial to wheat bran superfine grinding. The lower the crushing temperature is, the better the superfine grinding performance of wheat bran is. However, a lower crushing temperature reduces the economic performance of wheat bran superfine grinding, and it is not conducive to large-scale continuous, low-cost production of wheat bran. It has been shown that it is not necessary to reduce the temperature to under the glass transition temperature when wheat bran is crushed at low temperature ${ }^{[24]}$. Therefore, physical parameters such as density, elastic modulus, Poisson's ratio, yield strength and tangent modulus of wheat bran structure layers obtained by low temperature experiment, should be used for 
simulation analysis of the effects of low temperature conditions on crushing performance of wheat bran cell tissue to find the equilibrium point between the economic performance and the processing performance, and to obtained the optimum crushing temperature, which is suitable for the superfine grinding of wheat bran.

\section{Conclusions}

The superfine grinding of wheat bran belongs to the cellular level pulverizing. However, it is very difficult to reveal the fragmentation mechanism of cell tissue by observing the crushing process of cell tissue based on a superfine grinding experiment, which restricts the scientific selection and design of superfine grinding method, equipment and process. LS-DYNA can effectively solve all kinds of highly nonlinear problems and high-speed transient problems during the superfine grinding process of wheat bran. Therefore, the specific application of LS-DYNA in the determination of grinding form and load, the design and selection of grinding medium, and the selection of grinding temperature were discussed in the superfine grinding process for wheat bran cell tissue in this paper. The effect of macro pulverization on crushing performance of wheat bran cell tissue was analyzed by finite element numerical simulation, and it could be the beginning of revealing the crushing mysteries of wheat bran cell tissue in the superfine grinding process.

\section{Conflict of Interest}

The authors declare that there is no conflict of interest.

\section{References}

[1] OU Z B, WANG Q. Applications on grain and oil processing in micronized technology and its machinery[J]. Guangdong Agricultural Sciences, 2010, 37(7): 192-194.

[2] ZHANG J, YU Y, XU G H. Technology of superfine grinding and its application in food industry[J]. Journal of Agricultural Sciences, 2006, 27(2): 88-90.

[3] HEMER Y, CHAURAND M, HOLOPAINEN U, et al. Potential of dry fractionation of wheat bran for the development of food ingredients, part I: Influence of ultra-fine grinding $[\mathrm{J}]$. Journal of Cereal Science, 2011, 53(1): 1-8.

[4] ROSA N N, BARRON C, GAIANI C, et al. Ultra-fine grinding increases the antioxidant capacity of wheat bran[J]. Journal of Cereal Science, 2013, 57(1): 84-90.

[5] LI G H, WANG M J, DUAN Z C. Finite element simulation of the process of orthogonal metal cutting based on the ANSYS/LS-DYNA[J]. Transactions of the Chinese Society for Agricultural Machinery, 2007, 38(12): 173-176.

[6] WANG Z, ZHAO Y, YANG X L. Collision-contact, crack-fracture and penetration behavior analysis of thin-shell structures based on vector form intrinsic finite element[J]. Journal of Building Structures, 2016, 37(6): 53-59.

[7] LI Y H, SHAO L S, XU Z L. Numerical analysis for critical speed of coal impacting and comminution[J]. Journal of Vibration and Shock, 2017, 36(5): 227-230.

[8] KNIGHT N F, JAUNKY N, LAWSON R E, et al. Penetration simulation for uncontained engine debris impact on fuselage-like panels using LS-DYNA[J]. Finite Elements in Analysis and Design, 2000, 36(2000): 99-133.

[9] BARAUSKAS R, ABRAITIENE் A. Computational analysis of impact of a bullet against the multilayer fabrics in LS-DYNA[J]. International Journal of Impact Engineering, 2007, 34(7): 1286-1305.

[10] SU C, HOU J M, ZHU L D, et al. Finite element analysis of metal cutting process based on LS-DYNA[J]. Journal of Northeastern University (Natural Science), 2008, 29(9): 1334-1337.

[11] DORNEZ E, HOLOPAINEN U, CUYVERS S, et al. Study of grain cell wall structures by microscopic analysis with four different staining techniques[J]. Journal of Cereal Science, 2011, 54(3): 363-373.

[12] BAO C L, XU X Y, LIU B W. The nutrition and comprehensive utilization of wheat bran[J]. Cereals \& Oils, 2014, 27(8): 58-60.

[13] CHEN Z W, ZHA B P, WANG L, et al. Dissociation of aleurone cell cluster from wheat bran by centrifugal impact milling $[\mathrm{J}]$. Food Research International, 2013, 54(1): 63-71.

[14] GILLIES S A, FUTARDO A, HENRY R J. Gene expression in the developing aleurone and starchy endosperm of wheat[J]. Plant Biotechnology Journal, 2012, 10(6): 668-679.

[15] ANTOINE C, PEYRON S, MABILLE F, et al. Individual contribution of grain outer layers and their cell wall structure to the mechanical properties of wheat bran[J]. Journal of Agricultural and Food Chemistry, 2003, 51(7): 2026-2033.

[16] GREFFEUILLE V, MABILLE F, ROUSSET M, et al. Mechanical properties of outer layers from near-isogenic lines of common wheat differing in hardness[J]. Journal of Cereal Science, 2007, 45(2): 227-235.

[17] PEYRON S, CHAURAND M, ROUAU X, et al. Relationship between bran mechanical properties and milling behaviour of durum wheat (Triticum durum Desf.). Influence of tissue thickness and cell wall structure[J]. Journal of Cereal Science, 2002, 36(3): 377-386.

[18] CHENG Q, DENG L H. Finite element analysis of a three-dimensional viscoelastic model for cell deformation[J]. Guizhou Agricultural Sciences, 2009, 37(6): 33-35.

[19] FU Z Y, JIAO Q Y. Effect of osmosis on mechanical behavior of parenchyma plant cell under compressive loading[J]. Journal of China Agricultural University, 2005, 10(5): 5-9.

[20] GAO Y Y, JIAO Q Y, CHEN A H. Mechanics character analysis of plant cell to external shearing force[J]. Chinese Journal of Applied Mechanics, 2006, 23(4): 682-686.

[21] YUAN H X, YU J F. Theory and practice of ultra-fine pulverization and its impact on food industries[J]. Packaging and Food Machinery, 2001, 19(1): 5-10.

[22] FARBER B Y, KNOPJES L, BEDESI N. Advances in ceramic media for high energy milling applications $[\mathrm{J}]$. Minerals Engineering, 2009, 22(7-8): 704-709.

[23] YOUNAM H, FREDERIC M, MILENAR M, et al. Influence of water content and negative temperatures on the mechanical properties of wheat bran and its constitutive layers[J]. Journal of Food Engineering, 2010, 98(3): 360-369.

[24] CHEN H. Application of ultra-fine pulverizing in preparation of the whole wheat flour[J]. Cereals \& Oils, 2008, (8): 8-11.

[25] HUANG S, ZHU K X, QIAN H F, et al. Effects of ultrafine comminution and freeze-grinding on physico-chemical properties of dietary fiber prepared from wheat bran[J]. Food Science, 2009, 30(15): 40-44.

[26] MEGHWAL M, GOSWAMI T K. Cryogenic grinding of spices is a novel approach whereas ambient grinding needs improvement[J]. Advanced Powder Technology, 2010, 4(1): 427-435. 